\title{
Conceptualizing the Relationship between Stress, Job Satisfaction and Job Performance Using the Job Demand Control Support Theory: The Case of Firefighters in Malaysia
}

\author{
Mohammad Akramin Sakirun \\ Faculty of Business, Economics and Accountancy, Universiti Malaysia Sabah \\ Kota Kinabalu, Sabah, Malaysia \\ Oscar Dousin* (Corresponding author) \\ Faculty of Business, Economics and Accountancy, Universiti Malaysia Sabah \\ Kota Kinabalu, Sabah, Malaysia \\ E-mail: odousin@ums.edu.my/ oscardousin@gmail.com
}

Received: Nov. 12, $2021 \quad$ Accepted: Dec. 31, $2021 \quad$ Online published: Jan. 18, 2022

doi:10.5296/ijhrs.v12i1.19179 URL: https://doi.org/10.5296/ijhrs.v12i1.19179

\begin{abstract}
Malaysia's Fire and Rescue Department is the country's primary rescue organisation. However, in recent years, severe issues of stress affecting firefighters' job performance have been exposed in the media. The study aims to delve deeper into this topic by conceptualizing the impact of stress on job satisfaction and performance. The issue is conceptualized employing Karasek et al. (1988)'s Job Demand Control Support theory, which anticipated that the consequences of work stress or psychiatric illness are caused by the combination of job demand and job control. In terms of theoretical contributions, the study has enriched knowledge of JDCS theory in the context of firefighters in Malaysia. Meanwhile, in terms of human resource management contributions, this conceptualization will assist the Malaysian Fire and Rescue Department in better understanding the effects of stress on job performance and satisfaction, contributing to the emergence of efficient human resource policies to improve employee retention.
\end{abstract}

Keywords: job performance, job satisfaction, work-stress, non-work stress, Malaysia, firefighters 


\section{Introduction}

Malaysia's Fire and Rescue Department is the country's primary rescue organisation (Jabatan Bomba dan Penyelamat, Malaysia, 2013). The department's key tasks, as a high-quality and efficient organisation, are (i) extinguishing fires and saving lives, and (ii) mobilising all available resources to meet the department's purpose of being a high-performing organisation. According to Rizwan et al. (2014), the practice of mobilising limited current resources, mostly human resources, forces the department to make full use of its human resources by incorporating multitasking into daily routines. As a result of the overworked condition, Malaysian firefighters are exposed to a variety of hazards while doing their firefighting and rescue duties. According to Shah \& Lai (2001), excessive workload and hard labour can lead to increased work stress and a lack of workplace dedication. Other hazards on the job include potential exposure to smoke and chemical contamination. During their rescue operations, these threats could be extremely vulnerable and avoidable (Silverman et al). (2010). Workplace stress is described as a circumstance in which a person is pushed to act and is unable to cope with the normal mental strain (Behnoudi, 2005). Stress is also the body's response to changes that necessitate response, regulation, and physical, psychological, and emotional adjustment (Singh, 2001). It's also a personal sense of being overwhelmed, nervous, wrecked, pressured, fatigued, and sluggish (American Psychiatric Association, 2014). Because of its severe psychological and physiological impacts, as well as being the primary source of undesirable work behaviour such as productivity, turnover, and absenteeism, job stress is an important topic to examine and explore in relation to firefighters (Ibrahim \& Aida, 2012; Karasek \& Theorell, 1990).

The main research question of this study is: "How does stress influence job satisfaction and job performance?" while the main objective of the study is to explore and conceptualize the relationship between stress towards job satisfaction and performance among firefighters in Malaysia. Work-related stress, according to the study, can cause workplace accidents, increase the cost of occupational safety and health, increase trauma disorders, reduce work performance, and disrupt individual's social lives. This is a critical issue that needs to be addressed, especially in today's highly competitive public service climate, to maintain the organization's ability to carry out its responsibilities.

\subsection{Research Rationale and Theoretical Background}

According to several studies, work-related stress is the most significant factor influencing employee performance (Gilbao et al., 2008). Stress, if well-managed, can become a stimulant to work satisfaction since stress is also a challenging aspect; if stress does not exist, work will not be hard, and performance will likely suffer (Spector, 2003). The Malaysian fire and rescue department's strategic plan also noted that an organization's success is dependent on staff performance, therefore stress could be a possible predictor of employee work performance (Pelan Strategik Jabatan Bomba \& Penyelamat Malaysia, 2015). When there is no stress, occupational problems are thought to be absent, and performance is more likely to be low, according to Spector (2003). Because stress helps a person gather resources to meet job needs, performance tends to increase as stress rises. According to Evgenia (2016), 
occupational stress has a significant detrimental impact on job satisfaction. Non-work-related stress may also have an impact on job satisfaction and performance. Sauder et al. (1986) claimed that because family and career are intertwined and interdependent, home experience could potentially influence workplace quality and vice versa. Family and financial pressures, according to Karasek and Theorell (1990), can be a substantial source of difficult added stress. Furthermore, according to Ryerson and Livingston (2016), the presence of stress at work, either immediately after chronic stress at home or later, is likely to have a significant impact on the result. As a result, both work- and non-work-related stress may have a considerable impact on employee job satisfaction and performance. Employees' positive dedication and performance in achieving organisational success, as measured by job appraisal and work experience, is referred to as job satisfaction (Locke, 1976). Both work-related and non-work-related stress, on the other hand, can be harmful since employees may feel overwhelmed if they are unable to handle the challenges, leading to a loss in job satisfaction and poor performance.

Since, the firefighters and rescue profession are a critical technical profession, its nature of work is often challenging and risky work environment, thus the profession would likely experience a high work-related stress. This situation could lead to a drop in work productivity, low quality in teamwork and job performance (Russo \& Vitaliano, 1995). As firefighters and rescuers are a key technical profession, their nature of job is typically demanding and risky, and they are prone to experience significant levels of work-related stress. This condition could result in a decrease in work productivity, poor teamwork, and poor job performance (Russo \& Vitaliano, 1995).

To conceptualise the relationship between stress, job satisfaction, and job performance among Malaysian firefighters, the research utilised the Job Demand-Control (JDC) and Job Demand-Control-Support (JDCS) models. These models are foundational theories in research on the effects of occupational characteristics on health and wellbeing (Ibrahim \& Aida, 2012). Karasek's theory, which analyses the impact of work characteristics on stress, health, and occupational welfare, was first introduced in 1979. The JDC model was updated ten years later to account for workplace social support as a third predictor of well-being and strain, after greater emphasis to the function of workplace support in the stressor-strain process (Ganster, 1989). The job demand-control-support (JDCS) model was developed out of this expanded concept (Karasek et al., 1988). Karasek et al. (1998) indicate in their study that "firefighters" are high-stress positions with high demand and low job control, with recurring demands placed on them and few job possibilities. The JDC / JDCS Model, according to Pozo-Antunez et al. (2018), provides a complete framework for studying the direct and facilitative effects of this stress on employment. The JDC / JDCS model framework is very much in line with the study needs for firefighting stress evaluation, hence this theory is quite relevant to be employed in this research.

In Malaysia, there is currently little research examining and exploring the effects of work-related and non-work-related stress on job performance and satisfaction in the fire and rescue profession. The study's goal is to explore and conceptualise these issues among firefighters in Malaysia. Employment demands can be related to psychological demands such 
as mental workload, organisational limits in performing duties, or bearing expectations for conflict, according to the underlying idea of Job Demand Control-Support (JDCS) (Karasek, 1979) in the context of a firefighter's job. Furthermore, firefighters have high-stress jobs with high demand and poor job control, with frequent demands placed on them and few work options (Karasek, 1979; Karasek et al., 1998). As a result, a study that unravels the stress experienced by firefighters is required in order for the firefighting profession to become stronger and more capable of producing higher-quality jobs in keeping with the department's objective, leading to high-performing organisations.

\section{Literature Review}

\subsection{The Concept of Work Related and Non-Work Related Stress}

Work related stress is described as a physical and psychological reaction to threats arising from interactions between employees and the work environment, in which work demands exceed employee capabilities and existing resources as determined by the employer (Makanjee, 2004). According to a study conducted by Muchinsky (2003), workplace stress refers to individuals' perceptions and perceptions of environmental needs that exceed the resources available to them. Furthermore, work-related stress refers to a misalignment of environmental demand and human capacities or capabilities. According to Zafir and Fazilah (2006), there are three stages of stress that describe a person's level of stress: the warning stage, the resistance stage, and the tiredness stage, which are all referred to as General Adaptation Syndrome. The term 'general' refers to how stress affects different sections of the body, and 'adaptation' refers to the protective stimuli created to help the body absorb stress or control the stressor. Saiyaden (1993) mentioned in a previous study that stress happens everywhere in our culture and has become a part of daily life. Stress is an unavoidable byproduct of contemporary life. Rapid industrial growth, stress in metropolitan areas, population growth, and different challenges in daily life are some of the main causes of increased stress. Stress is a state of tension that has an immediate impact on a person's emotions, mental functions, and physical well-being. Furthermore, Work stress is also characterised by Meyer and Peng (2006) as a normal part of human existence that is differentiated by the level of stress they encounter, but if the stress is experienced repeatedly and excessively, it can damage a person's physical and mental health. As a result, work-related stress has become a prominent topic in organisational behaviour research for a variety of reasons, including stress's negative psychological and physiological impacts on employees. In recent studies, Mathangi (2017) defines work related stress as the result or response to certain stimuli in the environment. Factors such as heavy workloads, lifestyle and organisational climate could influence employee's stress level (Ivana, 2019; Munandar, 2011; Ford and Jin, 2015).

Non-work-related stress, on the other hand, refers to an actual or perceived imbalance between household roles and a family's ability to meet those expectations (Jones et al., 1988). Non-work stress is defined as stress or tension that occurs outside of the workplace and interferes with your normal everyday activities. Stress that is not caused by work can be 
defined as an actual imbalance or shadow between the expectations at home and the family's ability to meet those needs, according to Jones et al. (1988). Important life events such as marriage, having children, moving and changing jobs, as well as severe situations such as the death of a loved one or a natural disaster, all contribute to non-work-related stress (Emmons and McCullough, 2003). Organ and Hammer (1991) also said that marriage and divorce troubles, restricted time with family, problems with children, and lifestyle concerns such as alcohol misuse, excessive smoking, and less exercise are also causes of stress for firefighters outside of workplace settings. Long working hours, disrupted sex life, loss of friends (not firefighters) and death of coworkers or family members, low social status, anger and frustration at home or with family, emotions, intellectual and physical as well as the wife being alone at night and unable to help the family when needed are all issues that need to be addressed. Therefore, employees' ability to cope with growing work stress, according to Burr and Klein (1995), is also influenced by the amount of stress they experience outside of work.

\subsection{The Concept of Job Performance and Job Satisfaction}

Job performance is the outcome of an employee's contributions to the organisation in terms of his or her conduct, which the organisation may or may not consider productive (Zafir \& Fazilah, 2006). Furthermore, job performance refers to a set of employee behaviours that can be tracked, quantified, and evaluated at the individual level and related to organisational objectives (Murphy, 2008). As a result, work performance is a critical factor in determining organisational success. Job performance, according to Dessler (2000), relates to how individuals take action and contribute to behaviours that are consistent with organisational objectives, while individual task performance refers to the duties and tasks that a person needs to do. According to Oosthuizen and Koortzen (2007), job performance can be measured in two ways: (a) individual job performance and (b) actions that help create a social environment in the business, allowing others to carry out their responsibilities. Individual performance tasks entail learning tasks and settings in which a person is capable and motivated to complete activities when they are required. The notion of work performance differs significantly from one organisation to the next. Job performance should be determined by the nature of the work, how it is managed, and how it is organised. Despite the fact that the responsibilities are the same for two or more firms, job performance rating assessments may differ. Individual performance, for example, may be more stressful than group performance, because the evaluation will not take the organisation as a whole into consideration.

Job satisfaction, according to Spector (2003), is defined as favourable employee attitudes and behaviour that demonstrates positive commitment and higher performance to the organisation, resulting in the organization's success. Employee job satisfaction refers to their good impression of the important things they have accomplished. Parker and Axtell (2001) defined job satisfaction as a blend of complicated factors such as knowledge, emotion, and propensity. Furthermore, Sharkey and Davis (2008) stated that job satisfaction is the fulfilment of an individual's requirements as a result of his employment in the organisation.

Because many academics have concentrated on job satisfaction to learn in their research, 
Luthans (1985) indicated that job satisfaction is a significant issue in organisations. Makanjee (2004) identifies a number of elements that affect job satisfaction, including salary, advancement, supervision, self-employment, job collection, and working environment. Furthermore, job satisfaction is a crucial issue that management should address. Their productivity rises in direct proportion to their level of job satisfaction. On the other hand, if employee job satisfaction is low, it will affect job satisfaction negatively. Job satisfaction is defined in this study as a person's positive and negative feelings about his job, as well as to a group of people on the extent to which a person's feelings about his work, whether he likes or dislikes it, and this corresponds to job satisfaction among firefighters, as explained by Armstrong (2006).

\section{The Development of Research Hypotheses and Theoretical Framework}

Employee job performance is one of the primary factors that contribute to an organization's success, and stress is one of the main factors that contribute to their job performance level (Kumari et al., 2014). Employees with a stable marriage and health, high salaries, good relationships with managers, secure positions, and long career duration also reported low stress levels and positive job performance (Cho et al., 2015). Furthermore, issues such as work conflict, workloads, ambiguous job descriptions, insecure working positions, weariness due to workload, work quality, and quantity may all contribute to poor job performance (Moorthy, et al., 2013; Koopmans, 2013; Venkataraman \& Ganapathi, 2013). Apart from diminishing job performance, these issues would have a detrimental impact on employee job satisfaction (Gilbao et al., 2008; Lepine et al., 2005). As a consequence, we present the following hypothesis to show that work-related stress has a direct and negative impact on employee job satisfaction and performance:

H1: Work related stress is negatively associated with (a) job satisfaction and (b) job performance

According to Rowena et al. (2019), in the context of local government organisations, there is a significant relationship between stress and job satisfaction. Employee job performance and satisfaction can be impacted by non-work related stress such as physical and psychological health, life satisfaction, and organisational citizenship behaviour of employees outside of their necessary responsibilities, according to Spector (1997). Furthermore, according to Sarantakos (1996), family and work are interconnected and interdependent, so that experiences in one area influence the quality of life in the other. Non-work-related stressors such as inconsistent and absent family and household assistance, financial difficulties, and long-term family problems may have a harmful impact on job satisfaction and performance (Antoniou et al., 2003). These discussions have led to the following hypotheses:

H2: Non-work related stress is negatively associated with (a) job satisfaction and (b) job performance

Job satisfaction, according to Cronley and Kyoung Kim (2017), is a positive emotional state that is subjective to an individual's point of view and feelings about their job and organisation. 
Employees that are satisfied with the job will perform better at work, which will benefit the organization's performance and productivity (Abuhashesh et al., 2019). Job satisfaction has been linked to job performance, organisational citizen behaviour, organisational commitment, productive/ unproductive work behaviour, and job withdrawal, including absenteeism and turnover (Brohi et al., 2018; Shah et al., 2018). These debates lead to the following proposed hypothesis:

\section{H3: Job satisfaction has a significant influence on job performance}

Figure 1 below illustrates the study's proposed theoretical framework.

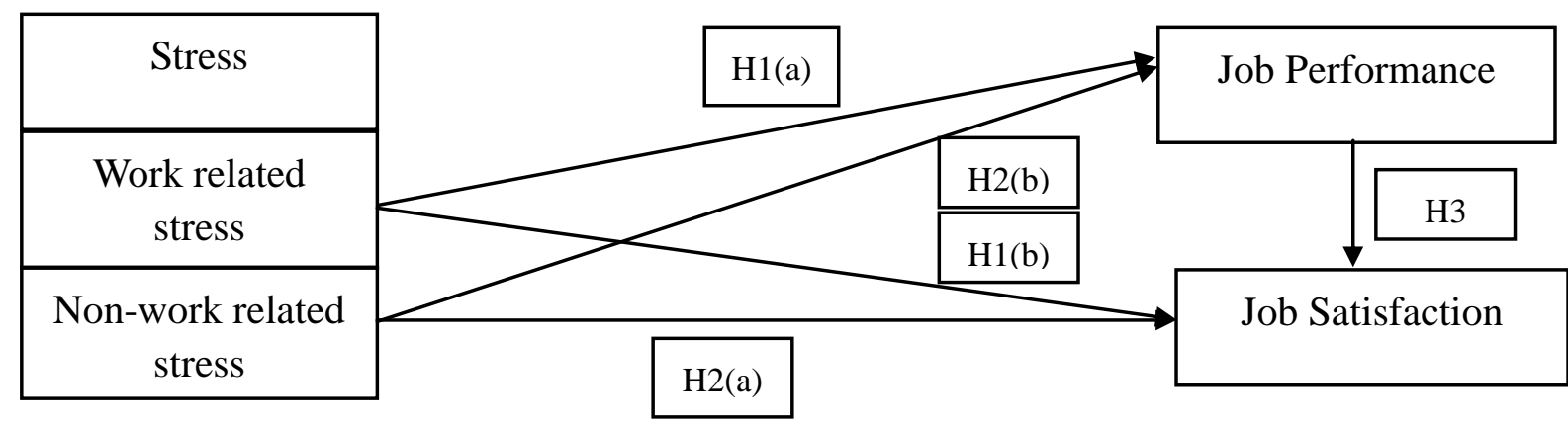

Figure 1.0. Theoretical framework

Note: Work-related and non-work related stress as independent variables while job performance and job satisfaction are dependent variables

\section{Context of the Study: The Firefighters Profession in Malaysia}

In Malaysia, firefighters have both essential and non-essential responsibilities. The specific duties of firefighters are established in section 5 of the Fire Services Act 1988, which stipulates that firefighter are responsible for extinguishing, resisting, preventing, and controlling fires. In the event of a fire, firefighters are also on call to defend lives and property. In addition, firefighters are involved as fire investigation officers under this sector and are on call to provide humanitarian assistance, such as life and property protection, in the event of a disaster. According to Rizwan et al. (2014), firefighters are also expected to fulfil other responsibilities such as government asset officers, government financial officers, and clerical officers, as well as cleaning the entire station. The addition of this work will increase stress levels, either directly or indirectly, which will influence job satisfaction and performance.

Firefighters are exposed to a variety of job risks as a result of the increasing workload crisis, particularly when doing firefighting and rescue activities. Too much workload or work, according to Shah and Lai (2001), can be stressful for employees. As a result, employees are unable to give the organisation their full devotion. The risk of being exposed to smoke hazards and chemical pollutants, among other things. Furthermore, according to Silverman et al. (2010), firefighting teams are exposed to smoke during firefighting and rescue operations, 
which is unavoidable. In the meantime, as per Sauder et al. (1986), family and career are strongly intertwined and interdependent, so home experience can affect the quality of the workplace and vice versa. Family and financial obligations also can be a major source of 'additional stress' (Lasky, 1995). As according to Ryerson and Livingston (2006), the incidence of stress at work, either directly following the occurrence of chronic stress at home or in combination with other severe pressures, might have a significant impact on the outcome. Previous research clearly shows that stress variables in the workplace have a direct impact on job satisfaction and performance among firefighters. Furthermore, because there are so numerous and complex firefighters, psychological issues such as stress will affect each and every one of them. That is to state, stress is a circumstance in which a person is compelled to act and is unable to cope with the normal mental tension (Behnoudi, 2005).

\section{Discussion}

The Malaysian Fire and Rescue Department (JBPM) is well aware that the current rapid expansion necessitates meticulous planning to guarantee that the Department remains on track and in step with the mainstream (Jabatan Bomba \& Penyelamat Malaysia, 2015). As a result, every firefighter will continue to try to maintain their competence and competitiveness in order to ensure that their work performance improves over time. Work performance is the consequence of an employee's quality and quantity of work in fulfilling their obligations related to their work with the responsibilities that have been assigned to them. The performance capabilities of an organization's employees have a significant impact on the achievement of the organization's goals and objectives. The effort is highlighted in the task assigned to them or in their own efforts, which stem from a strong desire to work more until the organization's goals are met. The ability to boost job performance and productivity is dependent on the organization's leader's or manager's knowledge of how to use economic resources, including human resources.

Stress associated to work and non-work related demands might be linked to psychological demands such as mental overload, organisational limits in performing duties, or bearing demand conflicts in the context of the fireman profession. According to Karasek's (1988) model, "firefighters" are high-stress workers with high demand and poor job control, where they are subjected to recurrent demands with few task possibilities. Increased job satisfaction, weariness, depression, and stress are all linked to employment that are in high demand with little control. Employees' ability to discover solutions to new problems is also limited, according to Karasek (1988) analysis, if a combination of total tensions cannot be resolved. As a result, employees with high job demand and little control are more likely to be carried away by their actual level of performance capacity while also being stressed and fatigued. As a result, this idea can be applied not only to the fire and rescue service, but also to other emergency response organisations like the police and army.

To encourage the organization's development and success, the organization's leadership, must take proactive actions to improve the organization's efficient process, which can be accomplished through continuous improvement of organisational practices. Employees are 
the most valuable assets owned by organisations, according to Rodgers et al. (1995). As a result, high-performing and productive people are produced in their organisations when they operate in a stress-free environment. However, if the business ignores stress-related issues and does not care about the problem, it can result in employee absenteeism, increased turnover rates, job inefficiency, and, in most cases, legal potential losses. Employees will become lethargic and unproductive if this issue is continually ignored, and it will also contribute to physical and mental problems. Stress studies in Malaysia should be improved in general because past studies on workplace stress were not comprehensive with little attention on the firefighter's profession. Workplace stress studies in this field are necessary because their input is critical to better understanding the nature of this profession as well as improving productivity, retention, and competitiveness.

\section{Conclusion}

The study confirmed and proposed a novel theoretical framework by situating work related and non-work related stress as significant antecedents to firefighters' job performance and satisfaction. Moreover, this conceptualisation confirmed the relevancy of Karasek (1979 \& 1988) JDCS model by endorsing 'firefighters' as a high-stress profession with high job demands which could negatively influence their job satisfaction and performance due to repetitive demands, fatigue and stress. At present, limited studies have explored the issues of stress and employee well-being (job satisfaction and job performance) among firefighters in Malaysia. Future study will be needed to confirm and corroborate the stated links in this conceptualization using an explanatory mixed-methods approach to gain a deeper understanding of the link between stress, job performance, and job satisfaction through empirical research. Mixed method studies are useful because integrating quantitative and qualitative methodologies allows phenomena to be better understood by capturing participants' rich, personal experiences (Dousin, 2017; Dousin et al., 2021; Weeks and Schaffert 2019). In phase one, the quantitative study will obtain an understanding of the relationships between the multilevel constructs of work related and non-work related stress to job satisfaction and performance. A qualitative study in phase two will expand on and clarify the findings of phase one by delving deeper into the firefighters' perspectives on the topic based on their personal experiences. The findings would provide a comprehensive explanation of the links between stress, job performance, and job satisfaction, which could be useful in understanding the nature of work for Malaysian firefighters.

\section{References}

Abuhashesh, M., Al-Dmour, R., \& Masa'deh, R. E. (2019). Factors that affect employees job satisfaction and performance to increase customers' satisfactions. Journal of Human Resources Management Research, 2019, 1-23.

American Psychiatric Association. (2014). Diagnostic and statistical manual of mental disorders

$(5$ th

Ed.).

Washington,

$\mathrm{DC}$,

USA. 
https://doi.org/10.1176/appi.books.9780890425596

Antoniou, A. S. G., Davidson, M. J., \& Cooper, C. L. (2003). Occupational stress, job satisfaction and health state in male and female junior hospital doctors in Greece. Journal of managerial psychology. https://doi.org/10.1108/02683940310494403

Armstrong, L. E. (2006). Nutritional strategies for football: counteracting heat, cold, high altitude, and jet lag. Journal of Sports Sciences, 24, 723-740. https://doi.org/10.1080/02640410500482891

Behnoudi, Z. (2005). Health and occupational stress. Tehran, Iran: Boshra-Tohfeh Publications: Tehran, Iran.

Brohi, N. A., Abdullah, M. M. B., Khan, A. M., Dahri, A. S., Ali, R., \& Markhand, K. H. (2018). Communication quality, job clarity, supervisor support and job satisfaction among nurses in Pakistan: The moderating influence of fairness perception. International Journal of Academic Research in Business and Social Sciences, 8(5), 1-6. https://doi.org/10.6007/IJARBSS/v8-i5/4078

Burr, W. R., \& Klein, S. R. (1994). Re-examining Family Stress New Theory and Research. Thousand Oaks, CA: Sage Publications, Inc.

Cho, M. K., Kim, C. G., \& Mo, H. J. (2015). Influence of interpersonal relation and job stress on nursing performance of male nurses. Journal of muscle and joint health, 22(3), 195-204. https://doi.org/10.5953/JMJH.2015.22.3.195

Cronley, C., \& Kyoung Kim, Y. (2017). Intentions to turnover: Testing the moderated effects of organizational culture, as mediated by job satisfaction, within the Salvation Army. Leadership \& Organization Development Journal. https://doi.org/10.1108/LODJ-10-2015-0227

Dessler, G. (2000). Human Resource Management. Upper Saddle River, NJ: Prentice Hall.

Dousin, O. (2017). Work-life balance practices in the healthcare industry: the case of East Malaysia (Doctoral dissertation, RMIT University).

Dousin, O., Collins, N., Bartram, T., \& Stanton, P. (2021). The relationship between work-life balance, the need for achievement, and intention to leave: mixed-method study. Journal of advanced nursing, 77(3), 1478-1489. https://doi.org/10.1111/jan.14724

Emmons, R. A., \& McCullough, M. E. (2003). Counting blessings versus burdens: an experimental investigation of gratitude and subjective well-being in daily life. Personal Social Psychologist, 84(2), 377-389. https://doi.org/10.1037/0022-3514.84.2.377

Evgenia, A. (2016). Occupational stress, job satisfaction, and employee loyalty in hospitality industry: a comparative case study of two hotels in Russia, Jun 2016, Vienna.

Ganster, D. C. (1989). Worker control and well-being: A review of research in the workplace. in S. L. Sauter, J. J. Hurrell, \& C. C. Cooper (Eds.), Job control and worker health (pp. 3-24). New York, NY: Wiley. 


\section{Mll Macrothink}

International Journal of Human Resource Studies ISSN 2162-3058

Gilboa, S., Shirom, A., Fried, Y., \& Cooper, C. (2008). A meta-analysis of work demand stressors and job performance: examining main and moderating effects. Personnel psychology, 61(2), 227-271. https://doi.org/10.1111/j.1744-6570.2008.00113.x

Gilboa, S., Shirom, A., Fried, Y., \& Cooper, C. (2008), A meta-analysis of work demand stressors and job performance: Examining main and moderating effects, Personnel Psychology, pp. 227-272 https://doi.org/10.1111/j.1744-6570.2008.00113.x

Ibrahim, R. Z., \& Aida, R. (2012). Psychosocial work environment, organisational justice and work family conflict as predictors of Malaysian worker wellbeing.

Jabatan Bomba \& Penyelamat Malaysia (2013). Buku laporan tahunan Jabatan Bomba dan Penyelamat Malaysia, Negeri Sabah. 2013.

Jabatan Bomba dan Penyelamat Malaysia. (2015). Pelan Strategik Jabatan Bomba \& Penyelamat, Malaysia.

Jones, J. W., Barge, B. N., Steffy, B. D., Fay, L. M., Kunz, L. K., \& Wuebker, L. J. (1988). Stress and medical malpractice: organizational risk assessment and intervention. Journal of Applied Psychology, 73(4), 727. https://doi.org/10.1037/0021-9010.73.4.727

Kain, J., \& Jex, S. (2010). Karasek's (1979) job demands-control model: A summary of current issues and recommendations for future research. In New developments in theoretical and conceptual approaches to job stress. Emerald Group Publishing Limited. https://doi.org/10.1108/S1479-3555(2010)0000008009

Karasek, R. A., Theorell, T., Schwartz, J. E., Schnall, P. L., Pieper, C. F., \& Michela, J. L. (1988). Job characteristics in relation to the prevalence of myocardial infarction in the US Health Examination Survey (HES) and the Health and Nutrition Examination Survey (HANES). American journal of public health,78 (8), 910-918. https://doi.org/10.2105/AJPH.78.8.910

Karasek, R., \& Theorell, T. (1990). Healthy work: Stress, productivity, and the reconstruction of working life. New York, NY: Basic Books.

Karasek, R., Brisson, C., Kawakami, N., Houtman, I., Bongers, P., \& Amick, B. (1998). The Job Content Questionnaire (JCQ): An instrument for internationally comparative assessments of psychosocial job characteristics. Journal of Occupational Health Psychology, 3(4), 322-355. https://doi.org/10.1037/1076-8998.3.4.322

Koopmans, L., Bernaards, C., Hildebrandt, V., van Buuren, S., Van der Beek, A. J., \& de Vet, H. C. (2013). Development of an individual work performance questionnaire. International journal of productivity and performance management. https://doi.org/10.1037/e577572014-108

Kumari, P., Bajwa, A., \& Priya, B. (2016). Relationship between stress and job performance: A study of banking sector. International Journal of Business Quantitative and Applied Management Research, 2(12), 91-106. 
Kumari, P., Bajwa, A., \& Priya, B. (2016). Relationship between stress and job performance: A study of banking sector. International Journal of Business Quantitative and Applied Management Research, 2(12), 91-106.

Lasky, R. G. (1995). Occupational stress: a disability management perspective. In D.E. Shrey\& M. Lacerete (Eds.). Principles and Practices of Disability Management in Industry, pp.370-409.

LePine, J. A., Podsakoff, N. P., \& LePine, M. A. (2005). A meta-analytic test of the challenge stressor-hindrance stressor framework: An explanation for inconsistent relationships among stressors and performance. Academy of management journal,48(5), 764-775. https://doi.org/10.5465/amj.2005.18803921

Locke, E. A. (1976). The nature and causes of job satisfaction. Handbook of industrial and organizational psychology. Chicago, IL: Rand McNally.

Luthans, F. (1985). Organizational Behaviour, McGill Illinois.

Makanjee, C. R. (2005). The effect of occupational stress and organizational commitment on diagnostic imaging radiographers in rendering quality service (Doctoral dissertation, University of Pretoria).

Meyer, K. E., \& Peng, M. W. (2005). Probing theoretically into Central and Eastern Europe: Transactions, resources, and institutions. Journal of international business studies, 36(6), 600-621. https://doi.org/10.1057/palgrave.jibs.8400167

Moorthy, M. K., Lee, J. Y., Hon, P. L., Khong, Y. M., Teow, A. N., \& Yeong, S. J. (2013). Determinants of job stress in affecting job performance: a study on the Malaysian banking $\begin{array}{llll}\text { sector. International Journal of Business } & \text { Excellence, 6(4), } 487 .\end{array}$ https://doi.org/10.1504/IJBEX.2013.054722

Muchinsky, P. M. (2003). Psychology Applied to Work. 7th Edition, Wadsworth, Belmont.

Murphy, K. R. (2008). Explaining the weak relationship between job performance and ratings of job performance. Industrial and Organizational Psychology, 1(2), 148-160. https://doi.org/10.1111/j.1754-9434.2008.00030.x

Oosthuizen, R. M., \& Koortzen, P. (2007). An empirical investigation of job and family stressors amongst firefighters in the South African context. South African Journal of Industrial Psychology, 33(1), 49-58. https://doi.org/10.4102/sajip.v33i1.252

Organ, D. W., \& Hammer, W. C. (1991) Organizational Behaviour: An Applied Psychological Approach, Business Publications: Texas.

Parker, S. K., \& Axtell, C. M. (2001). Seeing another viewpoint: Antecedents and outcomes of employee perspective taking. Academy of Management Journal,44(6), 1085-1100. https://doi.org/10.5465/3069390

Pozo-Antúnez, D., Joaquín, J., Ariza-Montes, A., Fernández-Navarro, F., \& Molina-Sánchez, H. (2018). Effect of a job demand-control-social support model on accounting professionals' 
health perception. International journal of environmental research and public health, 15(11), 2437. https://doi.org/10.3390/ijerph15112437

Rizwan, M., Raza, M. A., Mateen, M. A., Tehseen, F., Farooq, M. S., Javed, A., \& Javed, S. (2014). Investigating the causes of job stress: a study on banking sector of Bahawalpur, Pakistan. International Journal of Learning and Development, 4(2), 227. https://doi.org/10.5296/ijld.v4i2.6099

Rodgers, C. D., Paterson, D. H., Cunningham, D. A., Noble, E. G., Pettigrew, F. P., Myles, W. S., \& Taylor, A. W. (1995). Sleep deprivation: effects on work capacity, self-paced walking, contractile properties and perceived exertion. Sleep, 18(1), 30-38. https://doi.org/10.1093/sleep/18.1.30

Russo, J., \& Vitaliano, P. P. (1995). Life events as correlates of burden in spouse caregivers of persons with Alzheimer's disease. Experimental aging research,21(3), 273-294. https://doi.org/10.1080/03610739508253985

Ryerson, M. G., \& Livingston, B. (2006). FireFit. 6 TH WILDLAND FIRE SAFETY SUMMIT.[np]. 2006.

Saiyaden, M. A. (1993). Human Resource Management, New Delhi, McGraw-Hill.

Sarantakos, S. (1996). Children in three contexts: family, education and social development. Children Australia, 21(3), 23-31. https://doi.org/10.1017/S1035077200007173

Sarantakos, S. (1996). Modern families: an Australian text. Macmillan Education Australia.

Sauder, L. R., Chatham, M. D., Green, D. J., \& Kulle, T. J. (1986). Acute pulmonary response to formaldehyde exposure in healthy nonsmokers. Journal of occupational medicine.: official publication of the Industrial Medical Association, 28(6), 420-424. https://doi.org/10.1097/00043764-198606000-00008

Selye, H. (1956). The stress of life. New York: McGraw-Hill Co.

Shah, I. M. \& Lai, L. C. (2001). Gangguan Seksual Di Tempat Kerja Dan Hubungannya Dengan Tekanan Kerja Dan Kepuasan Kerja. Jurnal Teknologi, 34: pp. 51-64. Universiti Teknologi Malaysia

Shah, S. M. M., Ali, R., Dahri, A. S., Brohi, N. A., Maher, Z. A., \& Hameed, W. U. (2018). Determinants of job satisfaction among nurses: Evidence from South Asian perspective. International Journal of Academic Research in Business and Social Sciences, 8(5), 19-26. https://doi.org/10.6007/IJARBSS/v8-i5/4082

Sharkey, B. J., \& Davis, P. O. (2008). Hard work: defining physical work performance requirements. Human Kinetics, Champaign, IL.

Silverman, M. N., Heim, C. M., Nater, U. M., Marques, A. H., \& Sternberg, E. M. (2010). Neuroendocrine and immune contributors to fatigue. $P M \& R, 2(5), \quad 338-346$. https://doi.org/10.1016/j.pmrj.2010.04.008 


\section{Macrothink}

International Journal of Human Resource Studies

ISSN 2162-3058 2021, Vol. 12, No. 1

Singh, N. (2001). Organisational Behaviour: Concepts, Theory and Practices: Managing People and Organisations in the 21st Century. Deep and Deep Publications.

Spector, P. E. (1997). Job satisfaction: Application, assessment, causes, and consequences (Vol. 3). Sage. https://doi.org/10.4135/9781452231549

Spector, P. E. (2021). Industrial and organizational psychology: Research and practice. John Wiley \& Sons.

Steers, R. M. (1981). Introduction to organizational behavior. Goodyear Publishing Company.

Venkataraman, P. S., \& Ganapathi, R. (2013). A Study of Job Stress on Job Satisfaction among the Employees of Small Scale Industries. IOSR Journal of Business and Management (IOSR-JBM), 13(3), 18-22. https://doi.org/10.9790/487X-1331822

Weeks, K. P., \& Schaffert, C. (2019). Generational differences in definitions of meaningful work: A mixed methods study. Journal of Business Ethics, 156(4), 1045-1061. https://doi.org/10.1007/s10551-017-3621-4

Zafir, M. M., \& Fazilah, M. H. (2006). Stres di tempat kerja dan kesannya terhadap keselamatan dan kesihatan pekerjaan. Jurnal Kesihatan Masyarakat (Malaysia), 12(1), 1-10.

\section{Copyright Disclaimer}

Copyright for this article is retained by the author(s), with first publication rights granted to the journal.

This is an open-access article distributed under the terms and conditions of the Creative Commons Attribution license (http://creativecommons.org/licenses/by/4.0/). 